\title{
EVALUATION OF THE EFFECTIVENESS OF KREDIT USAHA RAKYAT (KUR) POLICY IN ENCOURAGING ECONOMIC GROWTH AND SOCIAL WELFARE IN CENTRAL JAVA PROVINCE
}

\author{
Werdha Candratrilaksita ${ }^{1}$ Hartuti Purnaweni ${ }^{2}$ dan Kismartini ${ }^{3}$
}

\begin{abstract}
1,283Universitas Diponegoro, Indonesia 1'werdhacandratrilaksita@gmail.com ²hartutipurnaweni@gmail.com 3kis_martini@yahoo.co.id
\end{abstract}

Submitted: 11 Juli 2020 Revised: 14 Agustus 2020 Accepted: 14 November 2020

\begin{abstract}
In 2018, Central Java could only absorb 26.22\% of KUR distribution in the production sector. The Non-Performing Loan (NPL), released by the Financial Services Authority, presented a lower production sector NPL than the trade sector. The agricultural sector was $1.85 \%$, the manufacturing sector was $3.19 \%$, and the trade sector was $4.45 \%$. In 2017, NPL of KUR Micro and Retail KUR of the agricultural sector amounted to $0.76 \%$, while the trade sector amounted to $1.44 \%$. The problem raised research questions: 1) Did the banks which distributed KUR and the Guarantor Institution experience a conflict of interest - between the public interest (the duty of the state to extend credit to MSMEs) and the interests of corporate entities (the task of seeking profits and avoiding risk), 2) Why was the lending of KUR in the production sector lower than the lending of KUR in the trade sector, and 3) How effective was KUR on economic growth and social welfare. To answer the research questions, researchers used a descriptive qualitative approach. Purposive sampling technique was used in this study. The finding showed dumping pricing policy tended to be misused by the banks which distributed KUR, and there was a conflict of interest and risk transfer in giving KUR. However, Small and Medium-sized Enterprises (UMKM) entrepreneurs who received KUR admitted that their profit was increased which also meant the improvement of social welfare.
\end{abstract}

Keywords: KUR, Production Sector, Value Added, Economic Growth, Subsidies

\section{PENDAHULUAN}

\section{Kebijakan Subsidi untuk Pertumbuhan Ekonomi}

Berbagai upaya dilakukan pemerintah, dalam rangka meningkatkan pertumbuhan ekonomi berbasis pemerataan. Pertumbuhan ekonomi berbasis pemerataan adalah pertumbuhan ekonomi yang didorong oleh kebijakan fiskal yang memperhatikan upaya penanganan kemiskinan dan ketimpangan melalui distribusi pendapatan baik dengan kebijakan bantuan sosial, maupun kebijakan subsidi. Kebijakan bantuan sosial bertujuan secara langsung mengentaskan kemiskinan, sedangkan kebijakan subsidi bertujuan untuk mendorong daya beli.

Kebijakan bantuan sosial merupakan amanat Undang-Undang Nomor 13 Tahun 2011 Tentang Penanganan Fakir Miskin dan Peraturan Presiden Nomor 15 Tahun 2010 Jo Peraturan Presiden Nomor 96 Tahun 2015 Tentang Percepatan Penanggulangan Kemiskinan. Kebijakan bantuan sosial diantaranya program keluarga harapan, program bantuan langsung tunai, dsb. Sedangkan kebijakan subsidi diantaranya : 1) subsidi bahan bakar minyak 
(Peraturan Presiden Nomor 191 Tahun 2014 Tentang Penyediaan, Pendistribusian, dan Harga Jual Eceran Bahan Bakar Minyak), 2) subsidi listrik (Peraturan Menteri ESDM Nomor 29 Tahun 2016 Tentang Mekanisme Pemberian Subsidi Tenaga Listrik Untuk Rumah Tangga), 3) subsidi pupuk (Peraturan Menteri Perdagangan Nomor 17/M-DAG/PER/6/2011 Tentang Pengadaan dan Penyaluran Pupuk Bersubsidi Untuk Sektor Pertanian), dan 4) subsidi bunga KUR (Amanat Undang-Undang Nomor 20 Tahun 2008 Tentang Usaha Mikro, Kecil, dan Menengah, Keputusan Presiden Nomor 14 Tahun 2015 Jo Keputusan Presiden Nomor 19 Tahun 2015 Tentang Komite Kebijakan Pembiayaan Bagi UMKM, serta Peraturan Menteri Koordinator Bidang Perekonomian Nomor 11 Tahun 2017 Tentang Pedoman Pelaksanaan Kredit Usaha Rakyat).

Kebijakan subsidi tersebut tidak akan berdampak pada pertumbuhan ekonomi, manakala tidak diikuti dengan upaya peningkatan nilai tambah dalam kegiatan perekonomian. Untuk itu, pemerintah menghadirkan kebijakan penjaminan dan subsidi bunga dalam Kredit Usaha Rakyat (KUR). Penjaminan dan subsidi bunga yang diberikan pemerintah pada dalam Kredit Usaha Rakyat (KUR), seharusnya berfokus pada kredit produktif, baik modal kerja maupun investasi, yang akan memberikan dampak pertumbuhan, karena menciptakan nilai tambah dalam perekonomian.

Kredit Usaha Rakyat (KUR) adalah kredit / pembiayaan untuk modal kerja dan / atau investasi untuk perorangan / kelompok, badan usaha dan / atau kelompok bisnis yang produktif dan layak tetapi belum memiliki jaminan tambahan atau jaminan tambahan yang tidak mencukupi, di mana pembiayaan menggunakan dana yang dimiliki oleh bank penyalur, dan pemerintah memberikan subsidi bunga.

\section{Kebijakan Subsidi Bunga dalam Pembiayaan bagi UMKM}

Undang-Undang Nomor 20 Tahun 2008 Tentang Usaha Mikro, Kecil, dan Menengah (disingkat UMKM), telah mengamanatkan kepada pemerintah, baik pemerintah pusat maupun pemerintah daerah, serta dunia usaha dan masyarakat, untuk melakukan lima hal, yaitu 1) pemberdayaan , 2) pengembangan, 3) pembiayaan, 4) penjaminan, dan 5) kemitraan. Pemberdayaan pada pelaku UMKM berbasis komunitas yaitu: 1) Penyelengaraan pelatihan kewirausahaan 2) Penyederhanaan perijinan usaha 3) Pengembangan jaringan kemitraan dengan stakeholders, dan 4) Promosi produk unggulan (Rochjadi et al., 2014) ${ }^{1}$. Sedangkan menurut Sudaryanto et al (2014) ${ }^{2}$, pemberdayaan UMKM harus dilakukan pemerintah melalui: 1) strategi meningkatkan daya saing industri, 2) strategi perluasan akses informasi jaringan pemasaran, dan 3) strategi meningkatkan kualitas sumber daya manusia pelaku UMKM.

Berbagai upaya pemberdayaan dan pengembangan telah dilakukan pemerintah, seperti pembentukan dan pencanangan sentrasentra UMKM, membantu dan mendorong tumbuhnya E-Commerce berbasis UMKM, melakukan pendampingan dan pelatihan bagi UMKM, memberikan kemudahan perijinan, serta berbagai fasilitas pembiayaan melalui mekanisme penjaminan maupun subsidi bunga.

Terdapat 58,97 juta UMKM di Indonesia (BPS, 2019), yang membutuhkan perhatian pemerintah dalam lima hal tersebut di atas. Diharapkan dengan diberikan akses pembiayaan akan mendorong UMKM bertumbuh, yang pada akhirnya mendorong terciptanya peningkatan penawaran dan permintaan agregat. Namun, persoalan yang dihadapi dalam penyaluran Kredit Usaha Rakyat adalah masih dominannya penyaluran di sektor perdagangan, sedangkan

1. Strategi Pemberdayaan Usaha Mikro Kecil dan Menengah (UMKM) Berbasis "Community Based Economic Development” (Studi pada pelaku UMKM di Kecamatan Sukodono Kabupaten Sidoarjo), Moch. Rochjadi Hafiluddin, Suryadil, Choirul Saleh, hlm 6, 2014, ISSN : 1411-0199

2. Strategi Pemberdayaan UMKM Menghadapi Pasar Bebas Asean, Sudaryanto et al, 2014, ISSN NO : 19786522 
sektor industri pengolahan, pertanian, dan usahausaha produksi lainnya tidak dominan mendapat penyaluran KUR. Padahal sektor tersebut, adalah sektor yang secara langsung mendorong nilai tambah dalam kegiatan ekonomi.

\section{Masalah Pertumbuhan Ekonomi dan Nilai Tambah dalam Perekonomian}

Tabel Pertumbuhan Ekonomi Provinsi Jawa Tengah Tahun 2011-2018

Sumber : Badan Pusat Statistik Provinsi Jawa Tengah (data diolah)

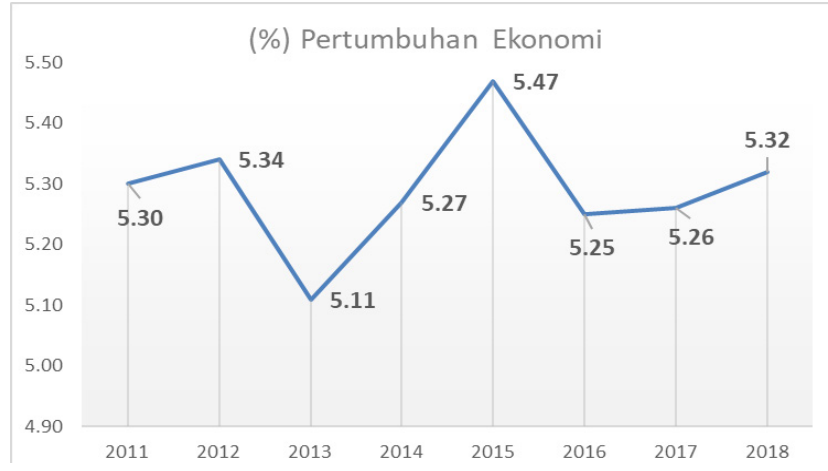

Laju pertumbuhan ekonomi di Jawa Tengah pada periode 2014-2018, di atas pertumbuhan nasional. Namun, kinerja perekonomian tersebut mendapatkan tantangan dengan masih berkisar di angka 5\%. Sedangkan target RPJMD Berdasarkan Peraturan Daerah Provinsi Jawa Tengah Nomor 5 Tahun 2014 tentang Rencana Pembangunan Jangka Menengah Daerah (RPJMD) Provinsi Jawa Tengah Tahun 2013-2018, sebesar 6,06,5\% untuk tahun 2015, dan sebesar 6,1-6,6\% untuk tahun 2016.

Laju pertumbuhan ekonomi Jawa Tengah merupakan laju kenaikan Produk Domestik Regional Bruto (PDRB) Jawa Tengah, yang didasarkan atas dasar perhitungan harga konstan suatu tahun dasar. PDRB menurut Badan Pusat Statistik (BPS, 2018) yaitu jumlah nilai tambah yang dihasilkan untuk seluruh wilayah usaha dalam suatu wilayah atau merupakan jumlah seluruh nilai barang dan jasa akhir yang dihasilkan seluruh unit ekonomi di suatu wilayah ${ }^{3}$.

Tabel Pertumbuhan Ekonomi Nasional dan

Provinsi Jawa Tengah Tahun 2011-2018

Sumber : Badan Pusat Statistik (data diolah)

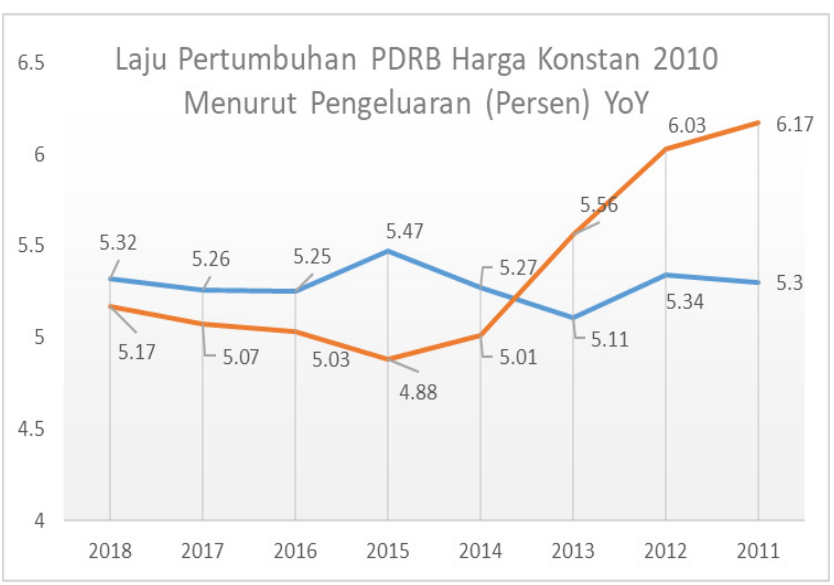

\section{Rendahnya Penyaluran KUR pada Sektor Produksi}

Tabel Penyaluran KUR Per Sektor di Jawa Tengah Tahun 2015-2018

Sumber : sikp.kemenkeu.go.id (Sistem Informasi Kredit Program Kementerian Keuangan, data diolah)

\begin{tabular}{|l|r|r|r|r|}
\hline \multicolumn{1}{|c|}{ KUR Per Sektor } & \multicolumn{1}{c|}{ Tahun 2015 } & \multicolumn{1}{c|}{ Tahun 2016 } & \multicolumn{1}{c|}{ Tahun 2017 } & \multicolumn{1}{c|}{ Tahun 2018 } \\
\hline Pertambangan & 0 & 0 & 0 & \\
\hline Perantaraan Keuangan & 0 & $75,000,000$ & $25,000,000$ & \\
\hline Konstruksi & $100,000,000$ & $537,000,000$ & $1,210,409,680$ & $17,925,000$ \\
\hline Jasa Perorangan & $1,200,882,200$ & $3,296,530,000$ & $9,709,000,000$ & $12,946,366,483$ \\
\hline Jasa Kesehatan & $1,700,000,000$ & $8,, 678,283,800$ & $9,950,000,000$ & $16,085,677,785$ \\
\hline Jasa Pendidikan & $2,172,500,000$ & $14,346,500,000$ & $13,501,000,000$ & $20,353,425,058$ \\
\hline Jasa Kemasyarakatan & $10,884,781,000$ & $26,571,764,400$ & $15,118,016,000$ & $25,554,709,800$ \\
\hline Real Estate & $18,909,621,200$ & $122,466,239,809$ & $106,880,971,480$ & $148,318,515,000$ \\
\hline Transportasi & $20,235,500,000$ & $147,017,536,800$ & $139,957,325,760$ & $163,121,824,480$ \\
\hline Penyediaan Akomodasi & $23,641,500,000$ & $220,799,386,000$ & $146,965,035,000$ & $230,817,076,631$ \\
\hline Perikanan & $28,663,000,000$ & $254,297,816,916$ & $249,113,869,462$ & $357,183,193,640$ \\
\hline Administrasi & $128,508,900,000$ & $309,136,006,000$ & $810,867,721,890$ & $1,196,365,981,551$ \\
\hline Industri Pengolahan & $250,681,230,000$ & $886,937,900,000$ & $1,132,536,140,025$ & $1,458,021,897,606$ \\
\hline Pertanian, Perburuan & $349,655,487,800$ & $3,101,818,862,900$ & $3,605,844,562,733$ & $3,931,826,266,484$ \\
\hline Perdagangan Besar & $2,122,794,022,222$ & $11,497,341,070,748$ & $10,288,203,213,870$ & $12,807,227,228,799$ \\
\hline \hline
\end{tabular}

3 https://www.bps.go.id/subject/52/ produk-domestik-regional-bruto--lapanganusaha-.html 
Penyaluran KUR di Jawa Tengah dari tahun 2015-2018 terbesar di sektor perdagangan, diikuti oleh pertanian, kemudian industri pengolahan. Pada tahun 2018, penyaluran KUR di sektor perdagangan sebesar Rp12,8 triliun atau 62,74\% (dari keseluruhan Rp20,36 triliun), sektor pertanian sebesar $19,12 \%$, dan industri pengolahan sebesar 7,1\%. Sektor pertanian dan sektor industri pengolahan merupakan sektor produktif, yang diharapkan mendapat penyaluran KUR sebesar 60\% dari target keseluruhan penyaluran KUR. Pada tahun 2018, Jawa Tengah hanya mampu menyerap 26,22\% penyaluran KUR pada sektor produktif tersebut. Sektor produktif lainnya adalah sektor perikanan dan sektor pertambangan, namun penyaluran di sektor tersebut sangat kecil atau tidak signifikan dibandingkan keseluruhan penyaluran KUR. Sehingga dikesampingkan dalam perhitungan.

Grafik Penyaluran KUR Per Sektor di Jawa

Tengah Tahun 2015-2018

Sumber : sikp.kemenkeu.go.id (Sistem Informasi Kredit Program Kementerian Keuangan, data diolah)

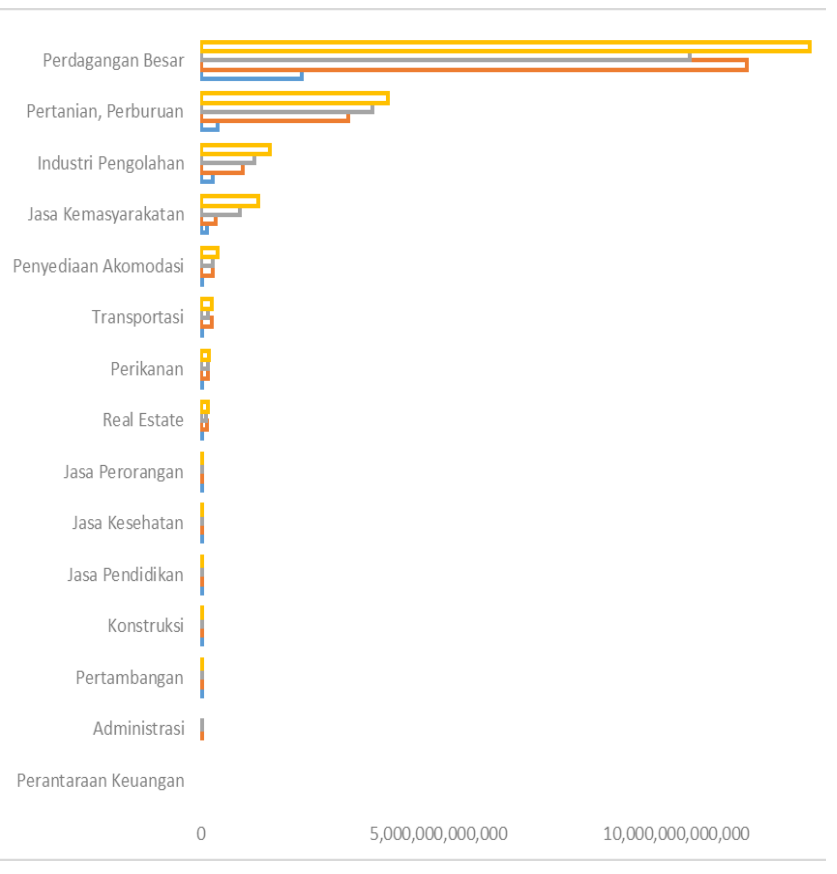

\section{REVIU LITERATUR}

\section{Teori Implementasi dan Evaluasi Kebijakan}

Analisis atas penyaluran KUR dilakukan dengan pendekatan model Grindle. Merilee S. Grindle dalam buku Politics and Policy Implementation in The Third World (1980), sebagaimana dikutip oleh Riant Nugroho dalam buku Public Policy (2018) bahwa setelah kebijakan ditransformasikan, maka implementasi kebijakan dilakukan. Keberhasilannya ditentukan oleh derajat implementability dalam isi (konten) kebijakan dan konteks kebijakan. ${ }^{4}$

Artikel ini ditulis menggunakan analisis konteks kebijakan mencakup:

1. Kekuasaan, kepentingan, dan strategi aktor yang terlibat

2. Karakteristik lembaga dan penguasa

3. Kepatuhan dan daya tanggap

\section{Teori Pertumbuhan Ekonomi}

Dalam usaha perdagangan, nilai tambah hanya dihasilkan dari biaya penjualan dan marjin keuntungan, sedangkan dalam usaha produksi nilai tambah dihasilkan dari biaya pengolahan (meliputi teknologi, tenaga kerja, dan risiko), biaya penjualan, dan margin keuntungan. Analisis nilai tambah merupakan metode perkiraan sejauh mana bahan baku yang mendapat perlakuan mengalami perubahan ini, sehingga menimbulkan nilai tambah yang dipengaruhi oleh teknologi yang digunakan dalam proses pengolahan (Eyverson Ruauw et al, 2012)5. Atas dasar hal tersebut, maka dalam kegiatan ekonomi masyarakat, industri pengolahan (manufaktur), industri eksplorasi (pertambangan, perikanan tangkap, dan perburuan), dan industri budidaya (perikanan, pertanian, dan peternakan) menyumbang nilai tambah terbesar terhadap PDRB.

Todaro dan Smith berpendapat bahwa

4. Nugroho, Riant. Public Policy. Cetakan keenam revisi ke-2 (2018). Halaman 745 5. Eyverson Ruauw et al, 2012. Analisis Keuntungan dan Nilai Tambah Agriindustri Manisan Pala UD Putri di Kota Bitung. ASE Volume 8 Nomor 1 
pendapatan nasional merupakan akumulasi nilai tambah di setiap sektor perekonomian (Todaro et al, 2015) $)^{6}$. Atas konsep tersebut, diformulasikan sebagai berikut:

$$
\mathrm{Y}=\sum \mathrm{ni}=1 \mathrm{VA}
$$

$\mathrm{Y}=$ pendapatan nasional

$\mathrm{n} \quad=$ jumlah sektor perekonomian dalam masyarakat

$\mathrm{VA}=$ nilai tambah yang dihasilkan di setiap sektor perekonomian

Untuk itu, dalam kebijakan KUR, fokus tujuan dan hasil adalah menciptakan nilai tambah dalam perekonomian, melalui intermediary yang dipraktekkan oleh perbankan. Pemilik idle cash dapat mengoptimalkan kas yang dimilikinya agar menghasikan nilai tambah dalam perekonomian, dengan cara menyalurkannya sebagai pembiayaan modal kerja dan investasi kepada para pelaku ekonomi yang mengalami kelangkaan modal (scarcity of capital) yang di-intermediary oleh perbankan.

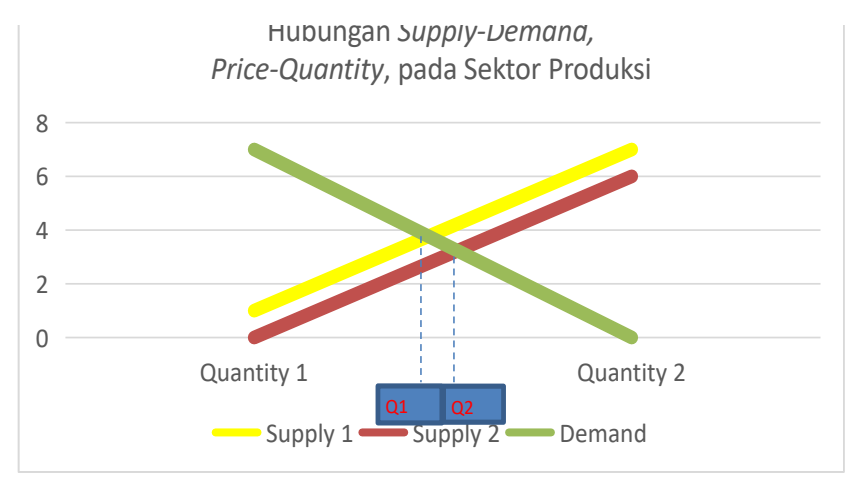

\section{MASALAH DAN METODE}

Masalah menimbulkan pertanyaan penelitian : 1) Apakah bank penyalur KUR dan Lembaga Penjamin mengalami benturan kepentingan, yaitu antara kepentingan publik (tugas negara untuk memberikan kredit kepada UMKM) dan kepentingan entitas perusahaan

6. Todaro, Michael P dan Smith, Stephen C. 2015. Economic Development, $12^{\text {th }}$ edition. George Washington University (tugas mencari keuntungan dan menghindari risiko), 2) Mengapa pencairan KUR di sektor produksi lebih rendah daripada pencairan KUR di sektor perdagangan, dan 3) Bagaimana efektivitas KUR terhadap pertumbuhan ekonomi dan kesejahteraan sosial.

Untuk menjawab pertanyaan penelitian, peneliti menggunakan pendekatan kualitatif dengan teknik analisis deskriptif. Data yang digunakan adalah data primer dan data sekunder. Data primer diperoleh dari survei lapangan, dengan informan yang terdiri dari: debitur KUR dan pejabat/pegawai bank penyalur di beberapa kota/kabupaten di Jawa Tengah. Data sekunder diperoleh dari 1) publikasi resmi, 2) penelitian terdahulu, 3) literatur, dan 4) berita media massa yang kredibel.

\section{PEMBAHASAN}

\section{Kekuasaan, Kepentingan, Dan Strategi Aktor Yang Terlibat}

1. Kekuasaan, Kepentingan, dan Strategi Publik/ Masyarakat

Publik/Masyarakat memiliki kekuasaan untuk menekan pemerintah agar pemerintah memenuhi Undang-Undang Nomor 20 Tahun 2008 Tentang Usaha Mikro, Kecil, dan Menengah. Publik khususnya pelaku UMKM berkepentingan untuk mendapatkan akses pembiayaan atau diprioritaskan dalam mendapatkan penyaluran kredit perbankan. Setelah kebijakan ditetapkan, masyarakat cenderung berusaha mengakses pembiayaan perbankan, melalui bank yang sudah dikenalnya. Sehingga, masyarakat yang belum mengenal perbankan atau belum pernah mendapatkan pembiayaan apapun dari perbankan akan cenderung dimarginalkan oleh perbankan. Padahal, masyarakat pelaku UMKM yang belum pernah mendapatkan pembiayaan dari perbankan tersebut, menjadi sasaran yang diharapkan oleh pemerintah untuk diprioritaskan oleh perbankan. 
2. Kekuasaan, Kepentingan, dan Strategi Pemerintah Pusat

Pemerintah pusat memiliki kekuasaan menurut undang-undang untuk memaksa bank umum menyalurkan kredit program sesuai skema yang ditetapkan pemerintah. Dengan terbitnya Peraturan Presiden Nomor 82 Tahun 2016 Tentang Strategi Nasional Keuangan Inklusif, Otoritas Jasa Keuangan (OJK) dan Bank Indonesia digandeng pemerintah pusat, untuk memberi efek daya paksa atas kebijakan kredit program yang telah dicanangkan pemerintah.

3. Kekuasaan, Kepentingan, dan Strategi Pemerintah Daerah

Pemerintah daerah memiliki kekuasaan atas APBD, dimana pemerintah daerah dapat menyusun dan menetapkan kebijakan kredit program tingkat pemerintah daerah, baik bekerja sama dengan bank umum pusat maupun bank umum daerah (Bank Pembangunan Daerah). Pemerintah daerah berkepentingan untuk memenuhi target RPJMD terkait pertumbuhan ekonomi, dan pemberdayaan pelaku UMKM. Sehingga, penyaluran KUR mendapat sambutan positif dari pemerintah daerah. Pada awal disalurkannya KUR, pemerintah daerah tidak diberikan kewenangan secara langsung, namun sejak diluncurkan SIKP (Sistem Informasi Kredit Program), pemerintah daerah diberikan hak untuk mengusulkan calon debitur serta memonitor pelaksanaan penyaluran KUR di daerahnya.

\section{Kekuasaan, Kepentingan, dan Strategi Bisnis Penyalur}

KUR berasal dari dana perbankan yang diperoleh dari dana pihak ketiga (DPK), yaitu berasal dari simpanan masyarakat di perbankan. Oleh karena itu, bank memiliki kekuasaan besar untuk menentukan kepada siapa, dana tersebut akan disalurkan. Di sisi lain, bank penyalur berkepentingan atas subsidi bunga pemerintah, dengan harapan dengan tingkat bunga rendah yang dibayarkan debitur, akan menjadi faktor pendorong mudahnya menyalurkan kredit ke masyarakat. Untuk itu, bank melakukan strategi kemitraan dan hubungan baik dengan pemerintah, dalam hal ini, dengan Komite Kebijakan Kredit Program.

5. Kekuasaan, Kepentingan, dan Strategi Bisnis Penjamin

Penjamin berkepentingan, agar Non Performing Loan (NPL) KUR rendah. Untuk itu, seharusnya menjadi pintu masuk bagi pemerintah untuk menggandeng kemitraan dengan lembaga penjamin untuk melakukan pembinaan terhadap debitur KUR. Pembinaan tersebut akan membantu debitur KUR untuk mampu dan berhasil dalam usahanya sehingga mampu mengembalikan pinjaman yang diterimanya. Pada akhirnya, secara kumulatif akan menurunkan angka NPL.

\section{Karakteristik Lembaga Dan Penguasa}

1. Karakteristik Publik/Masyarakat

Lembaga Pengelola Dana Bergulir Koperasi dan Usaha Mikro, Kecil dan Menengah (LPDB-KUMKM) sedang berupaya mengembalikan dana bergulir periode 20002007 yang masih bermasalah. Macetnya sebagian dana yang digulirkan senilai Rp 1,4 triliun itu, salah satunya akibat persepsi masyarakat bahwa pembiayaan bagi koperasi merupakan hibah. Memang, pada awal penyaluran dana terdapat petunjuk teknis (juknis) lewat instruksi Menteri Koperasi dan UKM yang menyebutkan dana tersebut merupakan hibah. Namun, menjelang 2004-2007, keluar juknis bahwa tidak ada lagi kata hibah. Artinya, dana tersebut harus dikembalikan. Meski demikian, persepsi tersebut hingga saat ini masih berkembang, sehingga dana bergulir masih terkendala untuk ditarik dan digulirkan lagi.

Untuk mengatasi hal itu, pendekatan bisnis perbankan harus dikedepankan dalam penyaluran KUR. Hal itu juga diterapkan dalam penyaluran Pembiayaan Ultra Mikro (UMi), dimana penyaluran UMi dilakukan dengan 
pendekatan bisnis. Strategi dan manajemen penyaluran dilakukan dengan pendekatan dan praktek yang berlaku di bisnis perkreditan.

\section{Karakteristik Pemerintah Pusat}

Dalam kebijakan KUR, pemerintah pusat bertindak sebagai regulator sekaligus sebagai evaluator. Pemerintah pusat tentunya bermitra dengan Bank Indonesia dan Otoritas Jasa Keuangan untuk mendorong terwujudnya suatu iklim keuangan inklusif yang menjadi amanat Bank Dunia, sebagai bagian dari Sustainable Development Goals (SDGs). Namun lebih daripada itu, adalah melaksanakan UndangUndang Nomor 20 Tahun 2008 Tentang Usaha Mikro, Kecil, dan Menengah.

Pemerintah pusat memiliki sumber daya yang cukup besar. APBN yang besar, lebih dari Rp2.0oo triliun, serta pelaksana program yang tersebar di berbagai instansi kementerian/lembaga, bahkan bermitra dengan OJK dan BI, menjadi kekuatan yang mendukung terimplementasikannya kebijakan KUR dan kredit program lainnya.

\section{Karakteristik Pemerintah Daerah}

Pemerintah daerah cenderung pasif dalam mendukung keuangan inklusif melalui serangkaian kredit program yang digulirkan pemerintah pusat. Untuk itu, Peraturan Presiden Nomor 82 Tahun 2016 Tentang Strategi Nasional Keuangan Inklusif, mengamanatkan agar pemerintah (dewan nasional dan kelompok kerja) memberikan pengetahuan keuangan inklusif kepada pemerintah daerah.

Meskipun, terdapat beberapa pemerintah daerah yang aktif menggalakkan program pembiayaan dengan skema kredit program di lingkup daerahnya, dengan menggunakan sumber daya APBD. Sebagai contoh, di Jawa Tengah, terdapat kredit “wibawa”, yang digulirkan pemerintah kota Semarang bekerjasama dengan OJK dan Bank Jateng, dengan bunga yang dibayarkan oleh debitur hanya $2 \%$ per tahun, serta kredit "laku semar" yang digulirkan pemerintah kabupaten Banyumas bekerjasama dengan OJK dan BPR/BKK, dsb.

\section{Karakteristik Penyalur}

Dalam menjalankan usahanya, bank memiliki prinsip yang dianut berdasarkan best practice maupun ketentuan yang diatur dalam Peraturan Bank Indonesia (PBI), yang meliputi : 1) prinsip kepercayaan, 2) prinsip kerahasiaan, 3) prinsip kehati-hatian, dan 4) prinsip mengenal nasabah. ${ }^{7}$

Kedua prinsip pertama, yaitu kepercayaan dan kerahasiaan adalah prinsip yang secara eksplisit termaktub dalam Undang-Undang Perbankan. Sedangkan prinsip kehati-hatian dan mengenal nasabah merupakan prinsip yang mendasari strategi pengembangan bisnis perbankan pada setiap bank. Namun, Bank Indonesia menerbitkan panduan pelaksaaan keempat prinsip tersebut dalam bentuk Surat Edaran BI (SEBI) maupun Peraturan Bank Indonesia (PBI).

Dalam konteks penyaluran KUR, prinsip kehati-hatian dan prinsip mengenal nasabah (Know Your Customer) seringkali menghambat inklusivitas KUR. Masyarakat yang tidak bankable namun feasible, mengalami kesulitan mendapatkan akses pembiayaan. Bank belum mengenal mereka, meskipun usahanya feasible. Untuk hal itulah, KUR hadir memberikan fasilitas pembiayaan bagi kelompok usaha yang tidak bankable namun feasible. Namun, dalam penyalurannya, bank penyalur hanya menyalurkan kepada nasabah yang telah dikenalnya. Hal itu tidak sepenuhnya salah, karena memang prinsip perbankan, salah satunya, adalah mengenal nasabah.

Dalam hal jaminan (collateral), sesuai Peraturan Menteri Koordinator Perekonomian Nomor 11 Tahun 2017 Tentang Pedoman Pelaksanaan KUR, bahwa nasabah KUR mikro tidak diwajibkan memberikan agunan tambahan.

\footnotetext{
7. Undang-Undang Nomor 7 Tahun 1992 Jo Undang-Undang Nomor 10 Tahun 1998 Tentang Perbankan
} 
Namun, pada kenyataannya bank penyalur tetap mewajibkan agunan tambahan. Bank penyalur beralasan untuk memenuhi prinsip kehati-hatian.

\section{Karakterstik Penjamin}

Asuransi diatur dalam Undang-Undang Nomor 40 Tahun 2014 Tentang Perasuransian dan Peraturan Otoritas Jasa Keuangan Nomor 73/ POJK.05/2016 Tentang Tata Kelola Perusahaan Yang Baik Bagi Perusahaan Perasuransian. Salah satu karakteristik perusahaan asuransi adalah underwriting, dimana perusahaan asuransi menilai tingkat resiko berdasarkan prinsip the law of large number. Prinsip tersebut menjadi dasar penentuan besaran premi, dimana semakin besar peluang (probabilitas) terjadinya risiko berdasarkan angka statistik, maka semakin besar premi yang ditetapkan.

Dalam penyaluran KUR, perusahaan penjamin akan menentukan besaran premi penjaminan berdasarkan NPL yang tersaji secara statistik. Semakin besar NPL, maka premi penjaminan semakin besar.

\section{Kepatuhan Dan Daya Tanggap}

\section{Tren Penyaluran Kredit}

Catatan Bank Indonesia (BI) dalam analisis uang beredar menunjukkan, sektor perdagangan hotel dan restoran (PHR) menyumbang setidaknya 20,74\% dari total kredit perbankan. Sektor ini pun tercatat tumbuh sebesar $9,69 \%$ year on year (yoy) pada bulan Agustus 2018 lalu. (keuangan.kontan.co.id, 2018)

Kredit komersial selain KUR mencatat penyalurannya pada sektor perdagangan hanya 20,74\% dari keseluruhan penyaluran kredit komersial. Namun, penyaluran KUR lebih banyak berada di sektor perdagangan. Pada tahun 2018, penyaluran KUR di sektor perdagangan di Jawa Tengah sebesar 62,96\%.

2. Pertumbuhan Sektor Perdagangan VS Sektor Produksi dalam PDB

Berdasarkan data Badan Pusat Statistik, sektor produksi berkontribusi terbesar bagi PDRB Jawa Tengah, yaitu pada tahun 2015 sebesar 51,37\%, pada tahun 2016 sebesar 50,84\%, pada tahun 2017 sebesar 50,06\%, dan pada tahun 2018 sebesar 49,34\%. Sedangkan sektor perdagangan pada tahun 2015 sebesar 14,31\%, pada tahun 2016 sebesar 14,36\%, pada tahun 2017 sebesar 14,47\%, dan pada tahun 2018 sebesar 14,52\%.

Sepanjang tahun 2015-2018, sektor produksi cenderung menurun, sedangkan sektor perdagangan cenderung meningkat. Penurunan sektor produksi bersesuaian dengan penurunan angka laju pertumbuhan ekonomi Jawa Tengah dari 5,47\% pada tahun 2015 menjadi 5,32\% pada tahun 2018. Untuk itu, peranan penyaluran KUR pada sektor produksi diharapkan lebih besar disalurkan daripada di sektor perdagangan.

\section{Tabel Komposisi PDRB Jawa Tengah \\ Berdasarkan Lapangan Usaha (\%)}

Sumber : Badan Pusat Statistik Provinsi Jawa Tengah, data diolah

\begin{tabular}{|c|c|c|c|c|}
\hline \multicolumn{5}{|c|}{$\begin{array}{l}\text { Komposisi PDRB Jawa Tengah Berdasarkan Lapangan Usaha Berdasarkan Harga Konstan } \\
\qquad 2010 \text { Untuk Periode 2015-2018 (\%) }\end{array}$} \\
\hline Lapangan Usaha & 2015 & 2016 & 2017 & 2018 \\
\hline A. Pertanian, Kehutanan, dan Perikanan & 14.11 & 13.7 & 13.23 & 12.89 \\
\hline B. Pertambangan dan Penggalian & 2.02 & 2.28 & 2.28 & 2.22 \\
\hline C. Industri Pengolahan & 35.24 & 34.86 & 34.55 & 34.23 \\
\hline D. Pengadaan Listrik, Gas & 0.11 & 0.11 & 0.11 & 0.11 \\
\hline E. Pengadaan Air & 0.07 & 0.07 & 0.07 & 0.07 \\
\hline F. Konstruksi & 10.08 & 10.2 & 10.38 & 10.45 \\
\hline $\begin{array}{l}\text { G. Perdagangan Besar dan Eceran, dan Reparasi } \\
\text { Mobil dan Sepeda Motor }\end{array}$ & 14.31 & 14.36 & 14.47 & 14.52 \\
\hline H. Transportasi dan Pergudangan & 3.32 & 3.31 & 3.34 & 3.41 \\
\hline I. Penyediaan Akomodasi dan Makan Minum & 3.11 & 3.14 & 3.17 & 3.26 \\
\hline J. Informasi dan Komunikasi & 4.09 & 4.21 & 4.53 & 4.83 \\
\hline K. Jasa Keuangan & 2.68 & 2.77 & 2.77 & 2.72 \\
\hline L. Real Estate & 1.84 & 1.86 & 1.89 & 1.89 \\
\hline M,N. Jasa Perusahaan & 0.34 & 0.36 & 0.37 & 0.38 \\
\hline $\begin{array}{l}\text { O. Administrasi Pemerintahan, Pertahanan dan } \\
\text { Jaminan Sosial Wajib }\end{array}$ & 2.75 & 2.68 & 2.61 & 2.59 \\
\hline P. Jasa Pendidikan & 3.63 & 3.71 & 3.77 & 3.85 \\
\hline Q. Jasa Kesehatan dan Kegiatan Sosial & 0.78 & 0.82 & 0.84 & 0.87 \\
\hline $\mathrm{R}, \mathrm{S}, \mathrm{T}, \mathrm{U}$. Jasa lainnya & 1.52 & 1.57 & 1.63 & 1.69 \\
\hline Produk Domestik Regional Bruto & 100 & 100 & 100 & 100 \\
\hline
\end{tabular}

3. Penyaluran KUR Sektor Produksi dan Sektor Perdagangan di Jawa Tengah

Di Jawa Tengah penyaluran KUR di sektor perdagangan jauh lebih besar dibandingkan sektor produksi. Berdasarkan data Sistem 
Informasi Kredit Program Ditjen Perbendaharaan Kementerian Keuangan, penyaluran KUR di Jawa Tengah pada tahun 2015 untuk sektor produksi hanya mendapat Rp629.099.717.800 atau $21,27 \%$, sedangkan sektor perdagangan mendapat Rp2.122.794.022.222 atau 71,76\%. Pada tahun 2016 sektor produksi hanya mendapat Rp4.136.386.299.700 atau 24,94\%, sedangkan sektor perdagangan mendapat Rp11.497.341.070.748 atau 69,32\%. Pada tahun 2017 sektor produksi hanya mendapat Rp4.886.581.147.438 atau 29,59\%, sedangkan sektor perdagangan mendapat Rp10.288.203.213.870 atau 62,30\%. Pada tahun 2018 sektor produksi hanya mendapat Rp5.565.934.280.053 atau 27,36\%, sedangkan sektor perdagangan mendapat Rp12.807.227.228.799 atau 62,96\%. Penyaluran KUR di sektor produksi dan sektor perdagangan tidak sebanding lurus dengan kontribusinya terhadap PDRB Jawa Tengah.

\section{NPL Per Sektor}

Tabel NPL Gross Lokasi (Spasial) Berdasarkan Sektor Ekonomi

\begin{tabular}{|l|r|r|r|r|r|r|r|r|r|}
\hline \multicolumn{1}{|c|}{ Regional } & Pertanian & Pertambangan & $\begin{array}{r}\text { Industri } \\
\text { Pengolahan }\end{array}$ & $\begin{array}{c}\text { Listrik, } \\
\text { Gas, dan } \\
\text { Air }\end{array}$ & Konstruksi & $\begin{array}{c}\text { Perdagangan } \\
\text { Besar }\end{array}$ & Transportasi & Lainnya & Rata-Rata \\
\hline Jawa & $2,03 \%$ & $7,70 \%$ & $3,36 \%$ & $1,37 \%$ & $2,65 \%$ & $4,25 \%$ & $3,80 \%$ & $1,87 \%$ & $\mathbf{2 , 8 6 \%}$ \\
\hline Sumatera & $1,94 \%$ & $11,63 \%$ & $1,84 \%$ & $5,09 \%$ & $8,13 \%$ & $5,01 \%$ & $2,73 \%$ & $2,05 \%$ & $\mathbf{2 , 9 3 \%}$ \\
\hline Kalimantan & $0,35 \%$ & $26,98 \%$ & $3,56 \%$ & $5,40 \%$ & $8,47 \%$ & $6,42 \%$ & $9,35 \%$ & $3,13 \%$ & $\mathbf{4 , 5 3 \%}$ \\
\hline Sulawesi & $1,64 \%$ & $2,39 \%$ & $3,29 \%$ & $1,27 \%$ & $6,27 \%$ & $4,47 \%$ & $3,29 \%$ & $2,02 \%$ & $\mathbf{2 , 9 2 \%}$ \\
\hline Bali dan Nusa Tenggara & $2,58 \%$ & $0,12 \%$ & $2,73 \%$ & $2,05 \%$ & $5,10 \%$ & $3,70 \%$ & $1,70 \%$ & $2,20 \%$ & $\mathbf{2 , 7 1 \%}$ \\
\hline Papua dan Maluku & $2,07 \%$ & $\mathbf{2 , 0 9 \%}$ & $1,78 \%$ & $0,19 \%$ & $10,53 \%$ & $4,54 \%$ & $5,41 \%$ & $1,85 \%$ & $\mathbf{2 , 6 2 \%}$ \\
\hline Rata-Rata & $\mathbf{1 . 8 2}$ & $\mathbf{8 . 1 3}$ & $\mathbf{3 . 1 9}$ & $\mathbf{1 . 4 7 \%}$ & $\mathbf{3 . 5 0}$ & $\mathbf{4 . 4 5 \%}$ & $\mathbf{3 . 9 3} \%$ & $\mathbf{1 . 9 7 \%}$ & $\mathbf{2 . 9 3 \%}$ \\
\hline
\end{tabular}

Grafik NPL KUR Mikro

Sumber : Otoritas Jasa Keuangan

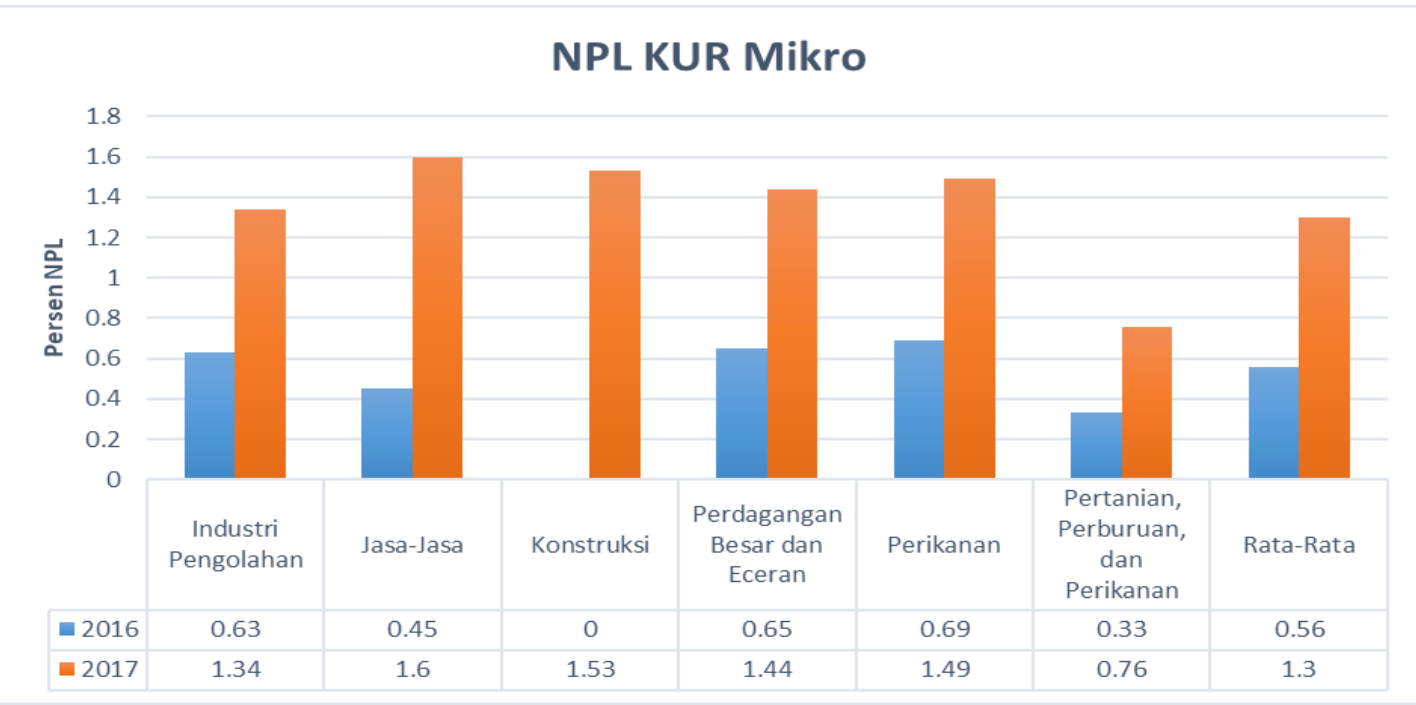




\author{
Grafik NPL KUR Ritel
}

Sumber : Otoritas Jasa Keuangan

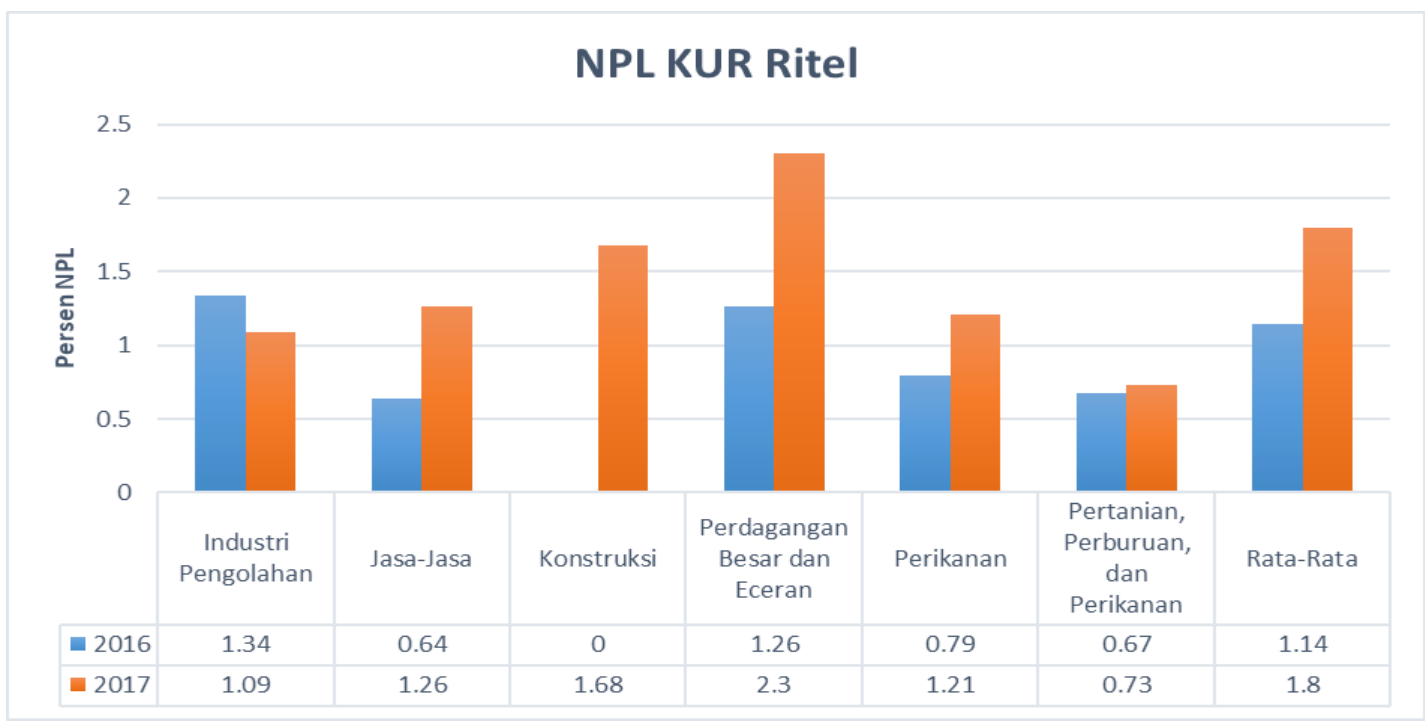

\title{
Matrik Analisis Konteks Kebijakan
}

\begin{tabular}{|c|c|c|}
\hline \multicolumn{3}{|c|}{ ANALISIS KONTEKS } \\
\hline Unsur & Faktor Pendorong & Faktor Penghambat \\
\hline $\begin{array}{l}\text { Kekuasaan, } \\
\text { kepentingan, } \\
\text { dan strategi } \\
\text { aktor yang } \\
\text { terlibat }\end{array}$ & $\begin{array}{l}\text { 1. Kepentingan UMKM } \\
\text { mendapatkan pembiayaan } \\
\text { (kredit) bersubsidi } \\
\text { 2. Kekuasaan pemerintah } \\
\text { bersama BI dan OJK untuk } \\
\text { memaksakan kredit program } \\
\text { kepada bank penyalur } \\
\text { 3. Kepentingan bisnis bank } \\
\text { penyalur untuk mendapatkan } \\
\text { manfaat pemasaran produk } \\
\text { pembiayaan dengan bunga } \\
\text { murah (bersubsidi) yang } \\
\text { cenderung diminati calon } \\
\text { debitur. lembaga } \\
\text { 4. Kepentingan untuk } \\
\text { penjamin risiko, } \\
\text { meminimalkan dissidi } \\
\text { dimana bunga yang disubsid } \\
\text { memperbesar tingkat } \\
\text { pengembalian debitur, } \\
\text { sehingga angka NPL turun. }\end{array}$ & $\begin{array}{l}\text { 1. Kepentingan bank penyalur } \\
\text { berpegang pada prinsip kehati- } \\
\text { hatian dan prinsip mengenal nasabah } \\
\text { (know your customer), menghambat } \\
\text { penyaluran KUR untuk kelompok } \\
\text { UMKM yang feasible namun tidak } \\
\text { dikenal bank (tidak bankable) } \\
\text { 2. Subsidi bunga dan penjaminan, } \\
\text { merupakan transfer risiko, yang } \\
\text { menghambat upaya pembinaan } \\
\text { debitur oleh bank penyalur dan } \\
\text { lembaga penjamin. Bank penyalur } \\
\text { dan lembaga penjamin berada di } \\
\text { zona aman, namun pemerintah yang } \\
\text { menanggung potensi risiko. }\end{array}$ \\
\hline
\end{tabular}




\begin{tabular}{|c|c|c|}
\hline $\begin{array}{l}\text { Karakteristik } \\
\text { lembaga dan } \\
\text { penguasa }\end{array}$ & $\begin{array}{l}\text { 1. APBN yang besar } \\
\text { memberikan peluang alokasi } \\
\text { belanja bunga kredit program } \\
\text { lebih besar } \\
\text { 2. Bank terbesar nasional } \\
\text { adalah bank BUMN, yang } \\
\text { cenderung mudah bermitra } \\
\text { dan diatur oleh pemerintah } \\
\text { 3. NPL KUR yang rendah } \\
\text { menjadi dasar penetapan } \\
\text { premi penjaminan yang } \\
\text { rendah (murah) }\end{array}$ & $\begin{array}{l}\text { 1. Anggapan publik bahwa KUR adalah } \\
\text { dana bergulir, yang bersifat hibah } \\
\text { atau bantuan sosial } \\
\text { 2. Kurangnya pemahaman dan inisiatif } \\
\text { pemerintah daerah untuk membentuk } \\
\text { program keuangan inklusif dan aktif } \\
\text { terlibat melakukan monitoring KUR } \\
\text { di daerahnya } \\
\text { 3. Masih adanya kewajiban debitur KUR } \\
\text { untuk menyertakan agunan tambahan }\end{array}$ \\
\hline $\begin{array}{l}\text { Ke p at u ha n } \\
\text { dan daya } \\
\text { tanggap }\end{array}$ & $\begin{array}{l}\text { 1. Sektorproduksiberkontribusi } \\
\text { terbesar pada pembentukan } \\
\text { produk domestik } \\
\text { 2. NPL sektor produksi, } \\
\text { khususnya pertanian dan } \\
\text { industri pengolahan lebih } \\
\text { rendah daripada sektor } \\
\text { perdagangan. }\end{array}$ & $\begin{array}{l}\text { 1. Penyaluran KUR sektor produksi lebih } \\
\text { kecil daripada sektor perdagangan } \\
\text { 2. Penyaluran kredit komersil lebih } \\
\text { banyak di sektor produksi. } \\
\text { 3. Bank penyalur diduga mengalihkan } \\
\text { risiko penyaluran kredit sektor } \\
\text { perdagangan yang ber-NPL tinggi, } \\
\text { dari kredit komersial kepada kredit } \\
\text { KUR, sedangkan penyaluran kredit } \\
\text { komersial berfokus di sektor produksi } \\
\text { yang ber-NPL rendah. }\end{array}$ \\
\hline
\end{tabular}

\section{HASIL SURVEI LAPANGAN}

\section{Hubungan Pemerintah Sebagai Provider dan Pelaku UMKM Sebagai Resipient Kebijakan}

Masyarakat dalam proses implementasi kebijakan KUR bertindak aktif dan tidak melakukan penolakan (reject), bahkan cenderung menerima dengan baik (accept). Sehingga kebijakan berjalan semestinya (implemented). Sedangkan pelaku UMKM adalah kelompok masyarakat yang berkepentingan atas kebijakan KUR dan paling menerima kebijakan KUR. Masyarakat dan pelaku UMKM bersikap pro aktif dengan mendorong pemerintah pusat dan pemerintah daerah untuk menfasilitasi atau menghubungkan antara pelaku UMKM dengan bank penyalur KUR. Masyarakat dan pelaku UMKM bertindak sebagai kelompok penekan, yang berkepentingan secara langsung atas kebijakan KUR. Oleh karenaitu, suara dan aspirasi yang disampaikan telah diperhatikan pemerintah sebagai sebagai bahan pertimbangan untuk dilakukan penyesuaian kebijakan. Beberapa kebijakan yang diatur dengan Peraturan Menteri Koordinator Perekonomian telah diubah setelah mendengarkan masukan dari masyarakat dan pelaku UMKM.

Pemerintah sudah menerima keluhan publik atas adanya agunan tambahan. Terhadap keluhan tersebut, pemerintah melakukan penyesuaian kebijakan kredit program dengan meluncurkan pembiayaan ultra mikro yang tanpa agunan. Pada kasus yang lain, pelaku UMKM sektor pertanian mengeluhkan kesulitan melakukan angsuran bulanan, maka pemerintah merespon dengan merevisi ketentuan angsuran KUR sektor pertanian, dimana angsuran dapat dilakukan setelah masa panen. Dalam hal kepemilikan kartu kredit, pelaku UMKM mengeluhkan bahwa memiliki kartu kredit 
menjadi penghambat mendapatkan KUR, maka pemerintah merespon dengan melakukan penyesuaian kebijakan KUR, dimanapemilikkartu kredit diizinkan mendapatkan KUR. Demikian juga untuk kelompok usaha berbentuk koperasi yang pada awal kebijakan tidak diperkenankan mendapatkan KUR, dengan adanya desakan dari pelaku UMKM berbentuk badan hukum koperasi, telah mendorong pemerintah melakukan penyesuaian kebijakan, dimana badan hukum koperasi dapat memperoleh KUR.

\section{Dampak Kesejahteraan Sosial}

Keseluruhan debitur KUR, yang dipilih secara random sampling untuk diwawancarai mengaku telah mengalami peningkatkan omset dan keuntungan, setelah mendapatkan pembiayaan KUR. Selain itu, tenaga kerja yang dipekerjakan bertambah. Secara makroekonomi, dampak kesejahteraan sosial dengan adanya KUR tidak terlihat, bahkan pertumbuhan ekonomi di Jawa Tengah sejak program KUR dengan mekanisme subsidi bunga diluncurkan, mengalami penurunan atau perlambatan. Sedangkan secara mikroekonomi, dampak kesejahteraan terlihat secara pasti dengan adanya peningkatan omset, keuntungan, dan tenaga kerja para debitur KUR.

\section{KESIMPULAN}

1. Kebijakan KUR dengan subsidi bunga dan penjaminan, adalah bentuk politik dumping bisnis pembiayaan, yang sangat berpotensi disalahgunakan oleh bank penyalur. Hal tersebut, disebabkan adanya benturan kepentinganbankpenyalurantarakepentingan penugasan negara untuk menyalurkan kredit program kepada kelompok UMKM sasaran, dengan kepentingan bisnis perbankan untuk mendapatkan keuntungan dan menghindari risiko.

2. Subsidi bunga dan premi penjaminan adalah bentuk Risk Transfer yang berpotensi merugikan negara, manakala penyaluran tidak tepat sasaran.

3. Dampak adanya benturan kepentingan dan risk transfer tersebut, adalah penyaluran kredit komersial perbankan difokuskan pada sektor-sektor ekonomi dengan NPL terendah seperti sektor produksi diantaranya pertanian dan industri pengolahan, namun penyaluran kredit KUR difokuskan pada sektorsektor ekonomi dengan NPL tinggi, seperti perdagangan besar dan eceran. Hal tersebut, menjadi faktor dominan yang menghambat penyaluran KUR pada sektor produksi.

4. Secara makroekonomi, penyaluran KUR belum dapat diukur kecenderungannya dalam mendorong pertumbuhan ekonomi. Namun, secara mikroekonomi, para pelaku UMKM yang menerima pembiayaan KUR, mengaku mengalami peningkatan omset dan keuntungan, yang berarti telah terjadi peningkatan kesejahteraan sosial.

\section{DAFTAR PUSTAKA}

Anderson, James E (Editor). University of Houston. 1982. Cases in Public PolicyMaking. Canada : Saunders College Publishing

Aziz, Abdul dan Wicaksono, Eko. 2016. Analisis Skema Alternatif Kredit Program Untuk Usaha Mikro, Kecil, Dan Menengah. Badan Kebijakan Fiskal Kementerian Keuangan

Nugroho, Riant. 2018. Public Policy Edisi 6 Revisi Kedua. Jakarta : Elek Media Komputindo

Sudaryanto et al. 2015. Strategi Pemberdayaan UMKM Menghadapi Pasar Bebas ASEAN. Badan Kebijakan Fiskal Kementerian Keuangan

Todaro, Michael P dan Smith, Stephen C. 2015. Economic Development, 12th edition. George Washington University

\section{Daftar Jurnal dan Laporan :}

Ashari. Optimalisasi Kebijakan Kredit Program Sektor Pertanian di Indonesia. Pusat 
Analisis Sosial Ekonomi dan Kebijakan Pertanian

Eyverson Ruauw et al, 2012. Analisis Keuntungan dan Nilai Tambah Agriindustri Manisan Pala UD Putri di Kota Bitung. ASE Volume 8 Nomor 1

Hafiluddin, Moch Rochjadi et al. 2014. Strategi Pemberdayaan Usaha Mikro Kecil dan Menengah (UMKM) Berbasis "Community Based Economic Development" (Studi pada pelaku UMKM di Kecamatan Sukodono Kabupaten Sidoarjo). Universitas Brawijaya. Vol 17 Nomor 2. ISSN : 14110199

Harefa, Mandala. 2015. Masalah dan Tantangan Implementasi Program Kredit Usaha Rakyat di Propinsi Sulawesi Selatan dan Jawa Tengah. P3DI Sekretariat Jenderal DPR RI.

Mahmudah, Henny. 2015. Analisis Pengaruh Pemberian Kredit Usaha Rakyat BRI Unit Laren Terhadap Peningkatan Keuntungan Usaha Mikro di Kecamatan Laren Kabupaten Lamongan. Jurnal EKBIS Vol XIII No 1 Edisi Maret 2015.

Otoritas Jasa Keuangan. Laporan Profil Industri Perbankan Triwulan III 2017. Badan Kebijakan Fiskal, Kementerian Keuangan. Laporan Tim Kajian Profil Sektor Riil : Sektor Perdagangan, Hotel, dan Restoran

\section{Daftar Peraturan :}

Undang-Undang Republik Indonesia Nomor 7 Tahun 1992 Tentang Perbankan

Undang-Undang Nomor 10 Tahun 1998 Tentang Perubahan Undang-Undang

Republik Indonesia Nomor 7 Tahun 1992 Tentang Perbankan

Undang-Undang Republik Indonesia Nomor 20 Tahun 2008 Tentang Usaha Mikro, Kecil, dan Menengah

Undang-Undang Republik Indonesia Nomor 40 Tahun 2014 Tentang Perasuransian
Peraturan Presiden Nomor 15 Tahun 2010 Jo Peraturan Presiden Nomor 96 Tahun 2015 Tentang Percepatan Penanggulangan Kemiskinan

Peraturan Presiden Nomor 191 Tahun 2014 Tentang Penyediaan, Pendistribusian, dan Harga Jual Eceran Bahan Bakar Minyak

Peraturan Presiden Nomor 82 Tahun 2016 Tentang Strategi Nasional Keuangan Inklusif

Peraturan Menteri ESDM Nomor 29 Tahun 2016 Tentang Mekanisme Pemberian Subsidi Tenaga Listrik Untuk Rumah Tangga

Peraturan Menteri Perdagangan Nomor 17/M-DAG/PER/6/2011 Tentang Pengadaan dan Penyaluran Pupuk Bersubsidi Untuk Sektor Pertanian

Peraturan Menteri Koordinator Bidang Perekonomian Nomor 11 Tahun 2017 Tentang Pedoman Pelaksanaan Kredit Usaha Rakyat

Peraturan Menteri Keuangan Nomor 253/ PMK.05/2016 Tentang Pedoman Penggunaan Sistem Informasi Kredit Program

\section{Daftar Referensi Daring :}

https://jateng.bps.go.id

https://keuangan.bisnis.co.id

https://keuangan.kontan.co.id

https://kur.ekon.go.id

https://sikp.kemenkeu.go.id

https://spanint.kemenkeu.go.id 